\title{
Plant Growth Pattern, Forage Yield, and Quality of Indigofera zollingeriana Influenced by Row Spacing
}

\author{
N. R. Kumalasari*, G. P. Wicaksono, \& L. Abdullah \\ Department of Nutrition and Feed Technology, Faculty of Animal Science, Bogor Agricultural University \\ Jalan Agatis, Kampus IPB Darmaga Bogor 16680, Indonesia \\ (Received 06-12-2016; Reviewed 21-02-2017; Accepted 14-03-2017)
}

\begin{abstract}
Indigofera zollingeriana is one of legumes has a great potential to be used as animal feed having high quality nutrients and is tolerant to different environmental conditions. The objective of this experiment was to study the effect of different row spacings between individual plants on growth pattern, forage yield, and quality of $I$. zollingeriana. Field experiment was conducted at Field Laboratory of Agrostology, Faculty of Animal Science Bogor Agricultural University, during the growing season of 2015/2016. The 4 spacings levels used were $1 \times 1.5 \mathrm{~m} ; 1 \times 1 \mathrm{~m} ; 1 \times 0.75 \mathrm{~m}$; and 1 × $0.5 \mathrm{~m}$. The treatment was arranged in a completely randomized block design, with 4 replicates. Variables in this research were plant height, number of leaves, number of branches, plant population for each plot, fresh and dry matter yields, and forage quality. The results showed that narrow plant spacing increased plant height, plant population, fresh and dry weights, dry matter yields, as well as NDF and $\beta$-carotene contents. The wider the plant spacing the greater the number of branches and leaves per plant. It was concluded that increasing plant population by narrowing plant spacing remained the most effective way to increase Indigofera forage yield without negative effects of it on nutritive values, i.e., crude protein, crude fat, crude fiber, ADF, and TDN.
\end{abstract}

Keywords: Indigofera, row spacing, plant growth, nutritive value, beta-caroten

\section{ABSTRAK}

Indigofera zollingeriana merupakan salah satu legum yang potensial untuk pakan ternak karena berkualitas tinggi dan toleran terhadap beragam kondisi lingkungan. Tujuan penelitian ini adalah untuk mempelajari pengaruh jarak tanam yang berbeda pada pola pertumbuhan, produktivitas dan kualitas hijauan I. zollingeriana. Penelitian ini dilaksanakan di Laboratorium Lapang Agrostologi, Fakultas Peternakan, Institut Pertanian Bogor pada musim tanam tahun 2015/2016. Jarak tanam yang digunakan adalah 1 × 1,5 m; 1 × $1 \mathrm{~m} ; 1$ x 0,75 m; dan 1 x 0,5 m. Penelitian ini menggunakan rancangan acak kelompok dengan 4 perlakuan dan 4 kali ulangan. Peubah yang diukur pada penelitian ini terdiri atas tinggi tanaman, jumlah cabang, jumlah daun, populasi tanaman per plot, produksi segar, bahan kering dan berat kering serta kualitas hijauan. Hasil penelitian menunjukkan bahwa jarak tanam pendek dapat meningkatkan tinggi tanaman, populasi tanaman, produksi segar, berat kering, bahan kering, NDF, dan $\beta$-karoten. Jarak tanam yang lebih lebar dapat meningkatkan jumlah cabang dan jumlah daun per tanaman. Kesimpulan penelitian ini adalah peningkatan populasi tanaman merupakan suatu metode yang efektif untuk meningkatkan produksi hijauan dengan memperkecil jarak tanam tanpa berpengaruh negatif pada nilai nutrisi protein kasar, lemak kasar, serat kasar, ADF, dan TDN.

Kata kunci: Indigofera, jarak tanam, pertumbuhan tanaman, kualitas, hasil panen

\section{INTRODUCTION}

Indigofera zollingeriana has a great potential to be used as a feed for ruminants, poultries, pets, and fisher-

${ }^{*}$ Corresponding author:

E-mail: nurrkumala@gmail.com ies. Indigofera contains high crude protein (27.60\%-31\%) (Palupi et al., 2014) and produces 4,096 kg DM leaf per hectare per harvest with 68 days of cutting time with in vitro DM digestibility of $67 \%-81 \%$ (Abdullah \& Suharlina, 2010). Indigofera has high nutrient contents that can be used as a feed supplement or as a sole forage to meet nutrient requirements and to sustain ruminant performance (Ginting et al., 2010). Good protein, amino 
acid, mineral, and vitamin contents of Indigofera also improves egg production and quality in quail (Faradillah et al., 2015).

The availability of high quality forage such as Indigofera plays important roles in increasing animal production and feed efficiency. This plant has a wide range of adaptation to various environmental conditions, tolerates to drought, light floods, and moderate salinity (Hassen et al., 2008). A common use of Indigofera cultivation is based on methods developed by Abdullah \& Suharlina (2010) that Indigofera plants are planted with a row space of $1.0 \times 1.5 \mathrm{~m}$. The cultivation of I. zollingeriana in a row space of $1.0 \times 1.5$ m may enhance the optimum plant of Indigofera in varied soil conditions (Ali et al., 2014). Since the efficiency of land use in producing nutrition for animal becomes an important issue in populated region, an evaluation of row spacing is needed to find an appropriate row spacing for planting Indigofera to produce the highest forage yield and quality. The changes in plant spacing is used as a tool to increase or decrease plant density (Murányi, 2015). New innovations in Indigofera production recommend the use of narrower row spacings.

Plant spacing is one of management aspects that determines the efficiency of land, light, water, and nutrients uses. A narrower row spacing increases crop's growth rate, dry matter accumulation, and seed yield (Pedersen, 2008). Plants spaced equidistantly from each other compete minimally for nutrients, light, and other factors (Agele et al., 2007). The narrow plant spacing had positive effects on plant density and yield per area (Murányi, 2015), green leaf area, plant height, number of leaves, final leaf number, and final leaf size (Streck et al., 2014). In addition, the narrow rows canopied more quickly, which reduced weed pressure (Grosbach, 2008) and weed biomass (Chauhan \& Opeña, 2013). In other side, the wider plant spacing had a positive effect on yield per plant and root (Streck et al., 2014).

The objective of this experiment was to evaluate the effect of different row spacings between plants on a growth pattern, forage yield and quality of I. zollingeriana, and find out an appropriate row spacing that results in a higher forage production and quality.

\section{MATERIALS AND METHODS}

The research was conducted at Field Laboratory of Agrostology, Faculty of Animal Science Bogor Agricultural University, in growing season of 2015/2016. The soil type in this field is latosol that predominantly clay loam (Baskoro \& Tarigan, 2011). Forage quality was analyzed at Laboratory of University Center (PAU), Integrated Laboratory of Faculty of Animal Science, and Animal Research Institute at Ciawi.

The treatments consisted of 4 equidistant spacings between rows and between plants: 1 x $1.5 \mathrm{~m}$; 1 x $1 \mathrm{~m}$; 1 x $0.75 \mathrm{~m}$; and $1 \times 0.5 \mathrm{~m}$, corresponding to the densities of 0.8 plant $/ \mathrm{m}, 1$ plant $/ \mathrm{m}, 1.3$ plants $/ \mathrm{m}$, and 1.5 plants $/ \mathrm{m}$, respectively. Each plot had a size of $3 \times 5 \mathrm{~m}$.

The basal fertilizer was an organic fertilizer (cattle manure) applied at the rate of $10 \mathrm{t} / \mathrm{ha}$ and was applied 2 weeks before planting, and inorganic fertilizers
(Phonska) at the rate of $50 \mathrm{~kg} / \mathrm{ha} / \mathrm{yr}$ and was applied 2 weeks after planting (surrounding the plant). The planting was performed using Indigofera seedling (4 weeks after sowing) with specified row spacing. Pruning was done after a month of grown in the experimental plots. The forages were trimmed approximately $100 \mathrm{~cm}$ above the ground using garden shears. This trimming would allow a new and uniform re-growth from where the experimental samples were later measured and harvested.

Growth attributes were measured from thirty percent of plant plots at random from the central ridges of each plot. Plant height $(\mathrm{cm})$ for each plant was measured from the base of the plant to the tip of central spike tassel. The number of leaves and branches per plant were counted from each selected plant then calculated the means. Plant population was counted from each plot to obtain the number of plants in a square meter and calculated the mean in a square meter. The growth attributes of selected plants were recorded during eight weeks after pruning.

Fresh yields from each plot were cut $60 \mathrm{~d}$ after cultivation. The plants were cut approximately $100 \mathrm{~cm}$ from the ground from each plot and directly weighed to determine the fresh yield. Then a plant was separated by branch, leaves, young leaves, and weighed to obtain the fraction weight of a plant. From the same plot, forages were composited and air dried, then weighed to obtain the dry matter yield.

\section{Chemical and Statistical Analysis}

Fresh herbage samples from each plot were taken $2000 \mathrm{~g}$ fresh weight, air dried under sunlight for $2 \mathrm{x}$ $12 \mathrm{~h}$, then the samples were dried in air-forced oven at $60^{\circ} \mathrm{C}$ for $48 \mathrm{~h}$, and ground to pass through a $1 \mathrm{~mm}$ sieve for chemical analyses. The dry matter (DM) and crude protein $(\mathrm{CP})$ contents were determined according to the AOAC (2005) procedure. Neutral detergent fiber (NDF) and acid detergent fiber (ADF) contents were estimated according to the method of Van Soest et al. (1991). $\beta$-Carotene contents were analyzed by HPLC method in Integrated Laboratory of Faculty of Animal Science.

The treatment was arranged in a completely randomized block design, with 4 replicates. The 4 spacings levels used were 1 × $1.5 \mathrm{~m}$; 1 × $1 \mathrm{~m}$; 1 × $0.75 \mathrm{~m}$; and 1 x $0.5 \mathrm{~m}$. Data were analyzed statistically with Analysis of Variance Test (ANOVA), and if there was a significant difference then the analyses was continued with Duncan's Multiple Range Test (DMRT).

\section{RESULTS}

\section{Plant Height}

The effect of space between plants on plant height of I. zollingeriana is presented in Figure 1. The results revealed that there was no significant difference in plant height between plant spacings until 3 weeks of measurement. The differences in plant height were detected between the row spacings in the fourth week of measurement. At the end of research, the narrowest plant spacing, $1 \times 0.5 \mathrm{~m}$ (P.5), gave the tallest mean plants 
height, i.e., $177.15 \mathrm{~cm}$ compared to $1 \times 1.5 \mathrm{~m}$ (P1.5), $1 \times 1$ $\mathrm{m}$ (P1), and $1 \times 0.75 \mathrm{~m}$ (P.75) of plant spacings.

\section{Number of Leaves per Plant}

The effect of space between plants on the number of leaves per plant of I. zollingeriana is presented in Figure 1. A significant difference $(\mathrm{P}<0.05)$ in the number of leaves per plant between row spacings was detected at the fifth week of measurement. The highest number of leaves per plant was recorded in plant spacing of P1.5 (1186.25 \pm 125.4$)$ and P1 followed by P.75 and P.5, respectively. The pattern of leaves number per plant was fluctuate for each week. In the seventh week of measurement, the number of leaves per plant in P1.5 increased up to the highest level, i.e., $2295.0 \pm 256.9$ leaves.

\section{Number of Branches per Plant}

The effect of space between plants on the number of branches per plant of I. zollingeriana is presented in Figure 1. A significant $(\mathrm{P}<0.05)$ difference in the number of branches per plant was detected between row spacings on the fifth week of measurement. The highest number of braches per plant was recorded in plant spacing P1.5 (208.75 cm), P1 (207.75), and P.75 (195.5) followed by P.5 (176.55).

\section{Plant Population}

The effect of space between plants on plant population of I. zollingeriana is shown in Table 1. A significant difference $(\mathrm{P}<0.05)$ in plant population was detected be-

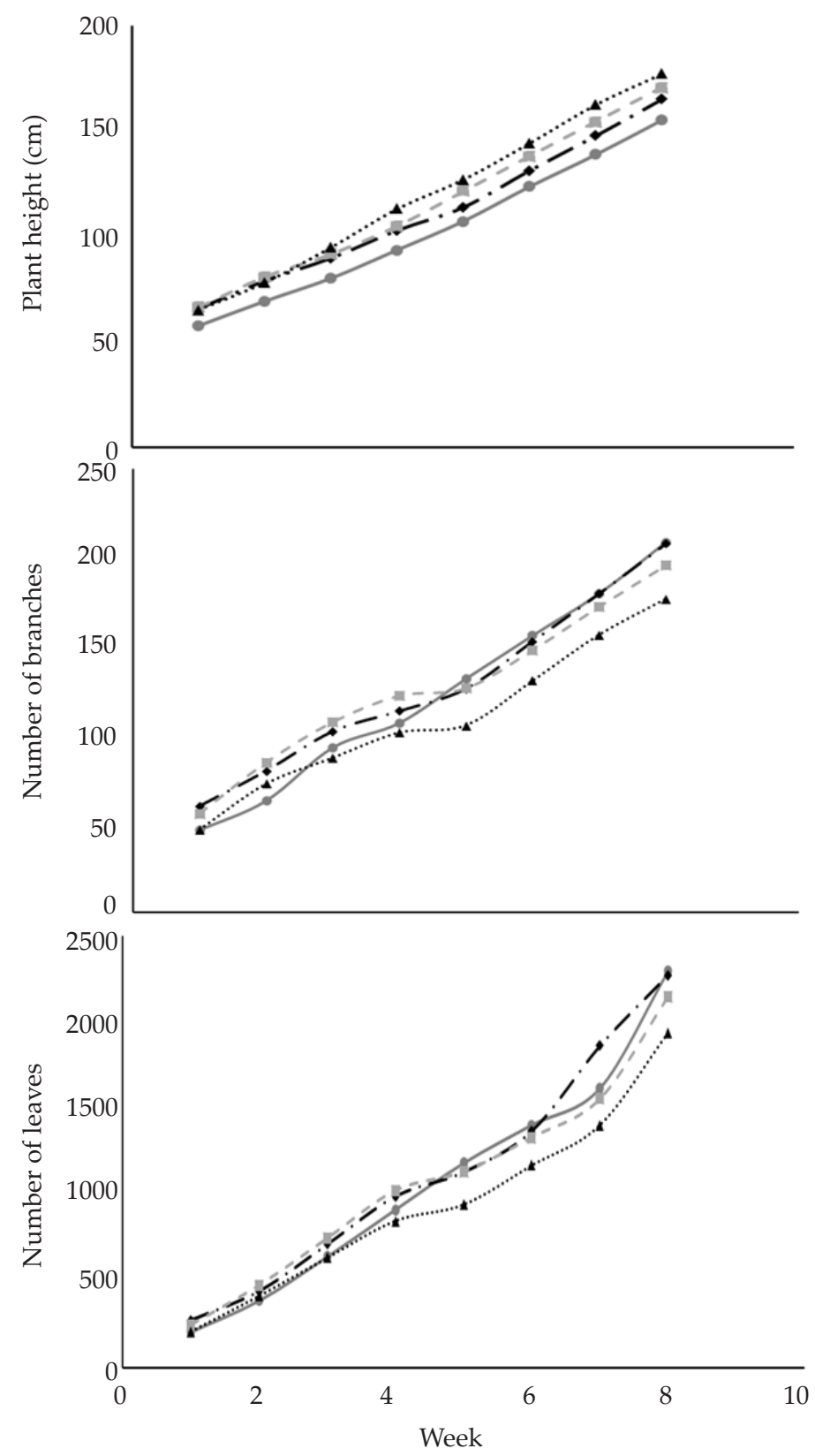

Figure 1. Plant height, number of branches, and number of leaves in different row spacings of Indigofera zollingeriana forage $(-\bullet-\mathrm{P} 1.5=$ row spacing $1 \times 1.5 \mathrm{~m} ;--\mathrm{P} 1=$ row spacing $1 \times 1 \mathrm{~m} ;-\mathbf{-}-\mathrm{P} .75=$ row spacing $1 \times 0.75 \mathrm{~m} ;-\boldsymbol{\Delta}-\mathrm{P} .5=$ row spacing $1 \times 0.5 \mathrm{~m}$ ). 
tween different row spacings. Narrow plant spacing (1 $x 0.5 \mathrm{~m})$ gave significantly $(\mathrm{P}<0.05)$ the highest number of plants per unit area, i.e., 30 plants per plot, compared to the plant spacing of $1 \times 1.5 \mathrm{~m}$ (12 plants), $1 \times 1 \mathrm{~m}$ (15 plants), and 1 x $0.75 \mathrm{~m}$ (20 plants).

\section{Forage Yield and Quality}

Forage yield. The effect of space between plants on fresh and dry weights of forage yield is presented in Table 1. There were significant differences in fresh and dry matter forage yields between different plat spacings. The highest fresh forage yield was recorded in the narrower plant spacing $(1 \times 0.5 \mathrm{~m})$ i.e., $10.88 \mathrm{~kg}$ fresh/plot and $3.56 \mathrm{~kg}$ dry/plot compared to those in $1 \times 1.5 \mathrm{~m}, 1 \times 1 \mathrm{~m}$, and $1 \times$ $0.75 \mathrm{~m}$ plant spacings.

Forage quality. The effect of space between plants on nutrient content is presented in Table 2. There were no significant differences in crude protein, crude fat, crude fiber, ADF, and TDN between different plant spacings. The significant effect of plant spacing was found on NDF and $\beta$-carotene content. The highest NDF content was recorded in the narrowest plant spacing $(1 \times 0.5 \mathrm{~m})$ i.e., $30.62 \pm 0.77 \%$ compared to those in $1 \times 1.5 \mathrm{~m}, 1 \times 1 \mathrm{~m}$, and $1 \times 0.75 \mathrm{~m}$ plant spacings. The pattern of $\beta$-carotene content was different from the other parameters: $\beta$-carotene contents on the narrowest and the widest plant spacing were higher than the other plant spacings.

\section{DISCUSSION}

Narrow plant spacing of Indigofera compared to standard row spacing had positive effects on whole- plant yield. The same results of different spacings effects on whole-plant yield was reported in corn that there was no negative effect of plant spacing on plant yield and nutritive value (Baron et al., 2006). Increasing plant population significantly increased the yield biomass, whereas plant spacing had a smaller effect on dry matter (Kuai et al., 2015). The positive relationship between row spacing and forage yield recommends the use of narrow row spacing for optimum Indigofera production. Narrow rows also can reduce the crowding of plants within a row, lessening the competition between individual plants and potentially enhancing the availabilities of light, water, and nutrients (Pioneer, 2015).

Increased narrow plant spacing up to $1 \times 0.5 \mathrm{~m}$ significantly increased plant height. The plant height curve during weeks of measurements follows a linear model (Figure 1). The increase in plant heights in a narrower spacing is probably be due to high rate of stem elongation. Stem elongation is related to the competition to get light between plants in narrow plant spacings that results in a significant taller plant compared to those in wider plant spacings (Craine \& Dybzinski, 2013).

In this research, the use of narrower row spacings than conventional row spacings reduces the number of branches and leaves significantly. It is likely that the greater distance between adjacent plants within rows enhances the abilities of the plants to convert the intercepted solar radiation to leaf production (Streck et al., 2014).

The changes in plant spacing in this research resulted in the increased plant population. The spacial arrangement of crop plants in a field such as row spacing and population adjustments in an attempt to improve yields and seed production (Stevovic et al., 2010). On the

Table 1. Plant population, dry matter, fresh weight, and dry weight of forage

\begin{tabular}{ccccc}
\hline Treatments & Number of plant $/ \mathrm{m}^{2}$ & Dry matter $(\%)$ & Fresh weight $(\mathrm{kg}) /$ plot & Dry weight $(\mathrm{kg}) /$ plot \\
\hline P1.5 & 0.8 & $25.40 \pm 3.87^{\mathrm{b}}$ & $5.82 \pm 1.25^{\mathrm{b}}$ & $1.45 \pm 0.20^{\mathrm{b}}$ \\
P1 & 1.0 & $27.02 \pm 4.10^{\mathrm{b}}$ & $6.66 \pm 3.10^{\mathrm{b}}$ & $2.11 \pm 1.26^{\mathrm{b}}$ \\
P.75 & 1.3 & $26.66 \pm 2.26^{\mathrm{b}}$ & $9.03 \pm 1.10^{\mathrm{a}}$ & $2.40 \pm 0.22^{\mathrm{b}}$ \\
P.5 & 1.5 & $32.74 \pm 1.28^{\mathrm{a}}$ & $10.88 \pm 1.13^{\mathrm{a}}$ & $3.56 \pm 0.32^{\mathrm{a}}$ \\
\hline
\end{tabular}

Note: Means in the same row with different superscripts differ significantly $(\mathrm{P}<0.05)$. $\mathrm{P} 1.5=$ row spacing $1 \times 1.5 \mathrm{~m} ; \mathrm{P} 1=$ row spacing $1 \times 1 \mathrm{~m} ; \mathrm{P} .75=$ row spacing $1 \times 0.75 \mathrm{~m} ; \mathrm{P} .5=$ row spacing $1 \times 0.5 \mathrm{~m}$.

Table 2. Nutrient content of Indigofera zollingeriana forage

\begin{tabular}{lccrr}
\hline \multicolumn{1}{c}{ Treatments } & \multicolumn{1}{c}{ P1.5 } & P1 & P.75 & P.5 \\
\hline Crude protein (\%) & $26.44 \pm 1.39$ & $25.55 \pm 2.32$ & $25.98 \pm 1.35$ & $25.17 \pm 0.81$ \\
Crude fat (\%) & $1.87 \pm 0.11$ & $1.88 \pm 0.27$ & $1.68 \pm 0.29$ & $1.87 \pm 0.24$ \\
Crude fiber (\%) & $12.83 \pm 0.34$ & $12.90 \pm 0.20$ & $12.09 \pm 0.17$ & $12.57 \pm 0.39$ \\
NDF (\%) & $29.15 \pm 1.10^{\mathrm{b}}$ & $27.49 \pm 0.30^{\mathrm{c}}$ & $28.96 \pm 1.00^{\mathrm{b}}$ & $30,62 \pm 0.77^{\mathrm{a}}$ \\
ADF (\%) & $27.64 \pm 1.90$ & $25.61 \pm 0.72$ & $25.77 \pm 1.66$ & $26.48 \pm 0.54$ \\
$\beta$-carotene (ppm) & $25.69 \pm 0.55^{\mathrm{a}}$ & $21.36 \pm 1.11^{\mathrm{b}}$ & $23.89 \pm 1.15^{\mathrm{a}}$ & $25.64 \pm 1.09^{\mathrm{a}}$ \\
TDN (\%) & $68.99 \pm 1.98$ & $68.27 \pm 3.84$ & $65.48 \pm 1.78$ & $64.63 \pm 2.25$ \\
\hline
\end{tabular}

Note: Means in the same row with different superscripts differ significantly $(\mathrm{P}<0.05)$. P1.5= row spacing $1 \times 1.5 \mathrm{~m}$; $\mathrm{P} 1=$ row spacing $1 \times 1 \mathrm{~m}$; $\mathrm{P} .75=$ row spacing $1 \times 0.75 \mathrm{~m} ; \mathrm{P} .5=$ row spacing $1 \times 0.5 \mathrm{~m}$. 


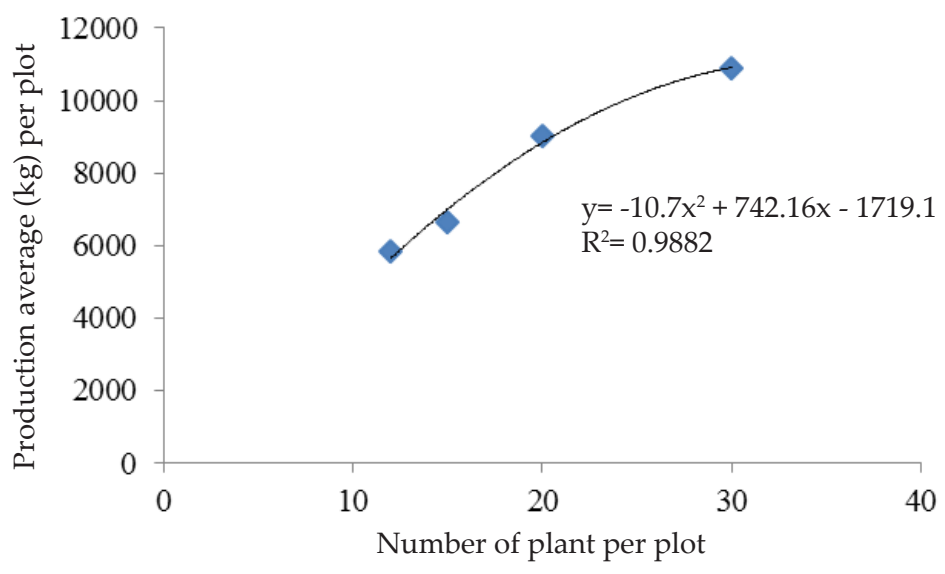

Figure 2. Correlation of plant population and production average of each plot of Indigofera zollingeriana forage

other hand, the increased plant population per unit area will approach an upper limit of production, plateau, and then declines (Figure 2).

Crude protein is an important parameter for forage quality. The crude protein contents of Indigofera in this research ranged between $25.17 \%-26.44 \%$ (SD 0.81-2.32). Crude protein contents of Indigofera in this research are in range of crude protein contents in Indigofera reported previously i.e., 23.1\%-29.83\% (Ali et al., 2014; Abdullah, 2010). The low protein content might be associated with the lower ability of plants to supply $\mathrm{N}$ for protein synthesis due to the absence of leaf fertilizer (Abdullah, 2010) and environmental condition (Ali et al., 2014).

ADF and NDF contents were found to be an important factor influencing nutritional quality of a plant. Row spacing did not affect the ADF concentration of Indigofera forage. ADF concentration varied from $25.61 \%$ to $27.64 \%$ that may be attributed to individual differences. This result was slightly different from previous research that reported the range of ADF content of Indigofera was $26.23 \%-45.29 \%$ (Abdullah \& Suharlina, 2010). Otherwise, there was a significant difference in NDF concentrations between the different row spacings. NDF concentrations ranging from $28.96 \%$ to $30.62 \%$ were lower than $38.30 \%-59.57 \%$ reported previously (Abdullah \& Suharlina, 2010). The NDF variation in this research correlated to the decreased row spacing. These results agree with the findings of Iptas \& Acar (2006) that NDF increases by the decrease in row spacing from the highest to the lowest.

The pattern of $\beta$-carotene content was different from that of NDF i..e., $\beta$-carotene contents increased with the decreased row spacing. $\beta$-carotene content in this research varied from 21.36 to $25.69 \mathrm{ppm}$, while the highest $\beta$-carotene was found in the widest plant spacing i.e., $1 \times 1.5 \mathrm{~m}$ (25.69 ppm). In contrast, Palupi et al. (2014) reported that young leaves of Indigofera contained $\beta$-carotene until $507.6 \mathrm{ppm}$. Ndiaye et al. (2016) revealed that $\beta$-carotene content accumulated in leaf area of legume despite the amount was different between species. Such differences in the results might be affected by environmental, cultural, and genetic factors (Iptas \& Acar, 2006). Elgersma et al. (2012) reported that the dif- ferences in $\beta$-carotene contents of legumes related to the interaction of plant species, fertilizer, and harvest time.

\section{CONCLUSION}

Increasing plant population remains the most effective way to increase Indigofera forage yield. Narrow row spacing had no negative effects on forage yield and nutritive value, i.e.: crude protein, crude fat, crude fiber, ADF, and TDN, while minor effects on forage nutritive value, i.e. increase $\beta$-carotene and NDF.

\section{ACKNOWLEDGEMENT}

This research was funded by The Directorate General of Higher Education, Ministry of Research, Technology and Higher Education through the Competency Grant (HIKOM) 2016.

\section{REFERENCES}

Abdullah, L. 2010. Herbage production and quality of shrub Indigofera treated by different concentration of foliar fertilizer. Med. Pet. 33: 169-175. https://doi.org/10.5398/ medpet.2010.33.3.169

Abdullah, L. \& Suharlina. 2010. Herbage yield and quality of two vegetative parts of Indigofera at different time of first regrowth defoliation. Med. Pet. 33:44-49.

Agele, S. O., I. O. Maraiyesa, \& I. A. Adeniji. 2007. Effects of variety and row spacing on radiation interception, partitioning of dry matter and seed set efficiency in late season sunflower (Helianthus annuus L.) in a humid zone of Nigeria. Afr. J. Agric. Res. 2: 080-088.

Ali, A., L. Abdullah, P. D. M. H. Karti, M. A. Chozin, \& D. A. Astuti. 2014. Production and nutritive value of Indigofera zollingeriana and Leucaena leucocephala in peatland. Animal Production. 16: 156-164

Baron, V. S., H. G. Nadja, \& F. C. Stevenson. 2006. Influence of population density, row spacing and hybrid on forage corn yield and nutritive value in a cool-season environment. Can. J. Plant Sci. 86: 1131-1138. https://doi. org/10.4141/P05-136

Baskoro, D. P. T. \& S. D. Tarigan. 2007. Soil moisture characteristics on several soil types. Jurnal Tanah dan Lingkungan. 9: 77-81. 
Chauhan, B. S. \& J. L. Opeña. 2013. Effect of plant spacing on growth and grain yield of soybean. Am. J. Plant Sci. 4: 2011-2014. https://doi.org/10.4236/ajps.2013.410251

Craine, J. M. \& R. Dybzinski. 2013. Mechanisms of plant competition for nutrients, water and light. Funct. Ecol. 27: 833840. https://doi.org/10.1111/1365-2435.12081

Elgersma, A., K. Søegaard, \& S. K. Jensen. 2012. Vitamin contents in forage herbs. Asp. Appl. Biol. 115: 75-80

Faradillah, F., R. Mutia, \& L. Abdullah. 2015. Substitution of soybean meal with Indigofera zollingeriana top leaf meal on egg quality of Cortunix cortunix japonica. Med. Pet. 38: 192197. https://doi.org/10.5398/medpet.2015.38.3.192

Ginting, S. P., R. Krisnan, J. Sirait, \& Antonius. 2010. The utilization of Indigofera sp as the sole foliage in goat diets supplemented with high carbohydrate or high protein concentrates. JITV. 15: 261-268

Grosbach, J. 2008. The effect of row spacing on the yield and plant growth of popcorn (Zea mays). Cantaurus. 16: 9-12

Hassen, A., N. F. G. Rethman, W. A. Z. Apostolides, \& Van Niekerk. 2008. Forage production and potential nutritive value of 24 shrubby indigofera accessions under fields conditions in South Africa. Tropical Grasslands. 42: 96-103

Iptas, S. \& A. A. Acar. 2006. Effects of hybrid and row spacing on maize forage yield and quality. Plant Soil Environ. 52: 515-522

Kuai, J., Y. Sun, Q. Zuo, H. Huang, Q. Liao, C. Wu, J. Lu, J. Wu, \& G. Zhoua. 2015. The yield of mechanically harvested rapeseed (Brassica napus L.) can be increased by optimum plant density and row spacing. Science Report. 5: 18835. https://doi.org/10.1038/srep18835

Murányi, E. 2015. Effect of plant density and row spacing on maize (Zea mays 1.) grain yield in different crop year. Columella-Journal of Agricultural and Environmental Sciences. 2: 57-63. https://doi.org/10.18380/SZIE. COLUM.2015.1.57.

Ndiaye, A., M. Diop, E. H. G. Diouf, \& S. Traore. 2016. Dosage of some chemical substances in two plant species: Alysicarpus ovalifolius (Sch. and Th.) and Indigofera pilosa (Poir). J. Biosci. Med. 4: 80-86

Palupi, R., L. Abdullah, D. A. Astuti, \& Sumiati. 2014. Potential and utilization of Indigofera sp. shoot leaf meal as soybean meal substitution in laying hen diets. Indonesian Journal of Animal and Veterinary Sciences (JITV). 19: 210-219

Pedersen, P. 2008. Row spacing in soybean. Department of Agronomy. Iowa State University.

Stevovic, V., R. Stanisavljevic, D. Djukic, \& D. Djurovic. 2012. Effect of row spacing on seed and forage yield in sainfoin (Onobrychis viciifolia Scop.) cultivars. Turk. J. Agric. For. 36: 35-44. https://doi.org/10.3906/tar-1006-1018

Streck, N. A., D. G. Pinheiro, A. J. Zanon, L. F. Gabriel, T. S. M. Rocha, A. T. de Souza, \& M.R. da Silva. 2014. Effect of plant spacing on growth, development and yield of cassava in a subtropical environment. Bragantia, Campinas. 73: 407-415. https://doi.org/10.1590/1678-4499.0159 